This item was submitted to Loughborough's Research Repository by the author.

Items in Figshare are protected by copyright, with all rights reserved, unless otherwise indicated.

\title{
Interrogating states' soft power strategies: a case study of sports mega- events in Brazil and the UK
}

\section{PLEASE CITE THE PUBLISHED VERSION}

http://dx.doi.org/10.1080/13600826.2015.1047743

\section{PUBLISHER}

Taylor and Francis / ( ) University of Kent

\section{VERSION}

AM (Accepted Manuscript)

\section{PUBLISHER STATEMENT}

This work is made available according to the conditions of the Creative Commons Attribution-NonCommercialNoDerivatives 4.0 International (CC BY-NC-ND 4.0) licence. Full details of this licence are available at: https://creativecommons.org/licenses/by-nc-nd/4.0/

\section{LICENCE}

CC BY-NC-ND 4.0

\section{REPOSITORY RECORD}

Grix, Jonathan, Paul M. Brannagan, and Barrie Houlihan. 2019. “Interrogating States' Soft Power Strategies: A Case Study of Sports Mega-events in Brazil and the UK". figshare. https://hdl.handle.net/2134/18470. 
Interrogating States' Soft Power Strategies: A Case Study of Sports Mega-Events in Brazil and the UK

JONATHAN GRIX, PAUL MICHAEL BRANNAGAN and BARRIE HOULIHAN

\begin{abstract}
Central to this article is the use of sports mega-events as part of a state's 'soft power' strategy. The article offers two things. First, a critique of the 'soft power' concept and a clearer understanding of what it refers to by drawing on the political use of sports mega-events by states; second, the article seeks to understand how and why sports mega-events are attractive to states with different political systems and at different stages of economic development. To this end a case study of an advanced capitalist state (London Olympics, 2012) and a so-called 'emerging' state (FIFA World Cup, 2014; Rio Olympics, 2016) will be undertaken in order to shed light on the role of sports events as part of soft power strategies across different categories of states.
\end{abstract}

Key Words: Soft power; sports mega-events; political use of sport; Brazil; UK 


\section{Introduction}

'Soft power' is in vogue. Not since the early 2000s has an academic concept been adopted so readily by politicians, policy-makers, media commentators and scholars alike. At that time, Robert Putnam's book ${ }^{1}$, 'Bowling Alone', and the attendant concept, 'social capital', were both fashionable and influential, informing policy on both sides of the Atlantic. Then, as now, the original concept was picked up, bandied about, misused and abused to an extent that it was rendered meaningless. Three similarities with the social capital debate are of importance for the present discussion: first, Joseph $\mathrm{Nye}^{2}$ clearly put his finger on something when coining the concept of 'soft power' - there has evidently been a shift in attempts to manipulate the 'politics of attraction' in international affairs among states of all political hues; second, the original concept was also ambiguous and unclearly defined; and third, there is still little agreement on what it is, whether, and under what conditions, either social capital or soft power can be created and maintained and if they actually have the impact on society and on the affairs which actors believe they affect. Finally, there is little consensus as to whether 'soft power' is a universal resource across ideologies, geographies, economies and cultures or simply a notion developed in, and pertaining to, the 'west'.

The purpose of this article is, therefore, two-fold. First, it sets about a ground-clearing exercise by making some important distinctions between several strands of (the multi-disciplinary) literature which are often conflated in discussions of soft power. Second, it draws on the use of sports mega-events by states as part of their soft power strategies, using the UK (London, 2012) and Brazil (FIFA World Cup, 2014; Rio, 2016) as case studies of an 'established' and 'emerging' state respectively. In doing so, the paper builds on the nascent IR literature analyzing sport as a lens through which to shed light on wider inter-state political machinations ${ }^{345}$ and contributes to turning the tide on the 'neglect of sport within the study of IR'. ${ }^{6}$ Far from simply a 'hobbyhorse', $^{7}$ the manipulation of sport and sports events by states for non-sporting aims offers unique insights into broader soft power strategies adopted by states to further their interests and improve their international standing.

\footnotetext{
1 Putman (2000) Bowling Alone: the collapse and revival of American community. New York: Simon \& Schuster Paperbacks.

2 Nye, J.S. Bound to Lead: The Changing Nature of American Power. (New York: Basic Books, 1990)

3 Black, D. (2008) 'Dreaming Big: The Pursuit of "Second Order" Games as a Strategic Response to Globalisation', Sport in Society, 11 (4), 467-80.

4 Cornelissen, S. (2014) 'South Africa's 'coming out party': Reflections on the significance and implications of the 2010 FIFA World Cup', in Grix, J. (2014) Leveraging Legacies from Sports Mega-Events. (Basingstoke: Palgrave).

${ }^{5}$ Levermore, R. and Budd, A. (eds) (2004) Sport and International Relations. (London: Routledge).

${ }^{6}$ Allison, L. (ed.) (2005) The Global Politics of Sport. London: Routledge, p. 7.

7 Grix, J. (2010). From hobbyhorse to mainstream: Using sport to understand British politics. British Politics, 5(1), 114-129.
} 


\section{The State of the Debate}

The concept of 'soft power' was coined in 1990 by the American political scientist, Joseph Nye. For Nye, the 'power' aspect of the concept refers to one's ability to 'effect the outcomes you want, and, if necessary, to change the behaviour of others to make this happen’ ${ }^{8}$. For national leaders, Nye suggests political outcomes can be attained through a combination of both 'hard' and 'soft' strategies. ${ }^{9}{ }^{10}$ On the one hand, leaders may utilize forms of 'hard power', through, for example, offering economic rewards or drawing on military force; on the other, leaders may indirectly adapt the political agenda in such a way which shapes the preferences of others through, for instance, emulating one's 'intangible assets': attractive culture, pioneering ideologies, and/or credible, legitimate and commendable institutions, values and policies. ${ }^{11}{ }^{12}{ }^{13}$ It is this latter approach which Nye calls 'soft power': 'the ability to achieve goals through attraction rather than coercion'. ${ }^{14}$ Such attraction converts into power outcomes when those on the receiving end of the soft power strategy look to the state producing it for affirmation, guidance and leadership, or seek to imitate their domestic and/or international achievements. ${ }^{15} 16$

This is not to suggest, however, that soft power should necessarily replace the utilization of hard power - in-fact national leaders should, whenever possible, endeavor to combine the soft dimension of attraction with the hard dimensions of coercion and inducement (what Nye terms 'smart power'). ${ }^{17}{ }^{18}$ Rather, Nye advocates that nation-states should take greater advantage of the former. ${ }^{19}{ }^{20}$ Nye's rationale for this is three fold. First, since the end of the Cold War, nationstates have become far more concerned with forms of welfare over military glory, whereby, in the modern era, national leaders need greater public support before engaging in forceful pursuits. ${ }^{21}$ Second, for the majority of powers, the use of force severely jeopardizes their

\footnotetext{
8 Nye, J.S. (2002) 'The Information Revolution and American Soft Power', Asia-Pacific Review, 9(1), p.2.

${ }^{9}$ Cf. Nye, J.S. Bound to Lead: The Changing Nature of American Power. (New York: Basic Books, 1990).

${ }^{10}$ Cf. Keohane, R.O and Nye, J.S. (1998) 'Power and Interdependence in the Information Age', Foreign Affairs, 77(5), 81-94.

11 Nye, J.S. (2002) 'The Information Revolution and American Soft Power', Asia-Pacific Review, 9(1), 60-76.

12 Nye, J.S. Soft Power: The means to success in world politics. (New York: Public Affairs, 2004).

13 Nye, J.S. (2008) 'Public Diplomacy and Soft Power', The ANNALS of the American Academy of Political and Social Science, 616(1), p. 95.

14 Keohane, R. O., \& Nye Jr, J. S. (1998). Power and interdependence in the information age. Foreign Affairs, 81-94. p.98.

15 Ibid.

16 Vuving, A. (2009) How Soft Power Works. Paper presented at American Political Science Association annual meeting, Toronto, $3^{\text {rd }}$

September. Available at: http://www.apcss.org/Publications/Vuving $\% 20 \mathrm{How} \% 20$ soft $\% 20$ power $\% 20$ works $\% 20 \mathrm{APSA} \% 202009$.pdf

17 Nye, J.S. (2008) 'Public Diplomacy and Soft Power', The ANNALS of the American Academy of Political and Social Science, 616(1), pg. 94.

18 Cf. Nye, J.S. (2006) Think Again: Soft Power. Foreign Policy [online]. Available:

http://www.foreignpolicy.com/articles/2006/02/22/think again soft power (Accessed: 12th January 2014).

19 Nye, J.S. Bound to Lead: The Changing Nature of American Power. (New York: Basic Books, 1990)

${ }^{20}$ Nye, J.S. (2004) 'Soft Power and American Foreign Policy', Political Science Quarterly, 119(2), 255-270.

${ }^{21}$ Nye, J.S. (2002) 'The Information Revolution and American Soft Power', Asia-Pacific Review, 9(1), 60-76.
} 
economic objectives and ability to maintain international competitiveness. ${ }^{22}{ }^{23}$ Finally, the increasing influence of the information revolution and globalization has led to states' behavior coming under closer scrutiny than ever before. ${ }^{24}{ }^{25}$ The result is that the use of force has become less tolerated in post-industrial (and, in particular, advanced capitalist) societies, leading to the increasing significance of soft forms of power. ${ }^{26}$

The consequence of this heightened significance has resulted in soft power becoming well and truly bound up within a multiplicity of contemporary discourses. First off is the academic: commentators' endeavors to unpick, understand and extend soft power conceptually, but in line with Nye's original thinking; ${ }^{27} 28$ second, are those commentators who have used the concept to explain various socio-political phenomena in specific locales, for example, Lam $^{29}$ who situates Japan's successful export of manga and anime as part of a wider search for cultural attraction and soft power; Kalin ${ }^{30}$ who draws heavily on Nye's concept to explain some of the more recent socio-economic and political shifts in Turkey's foreign policy; Gallarotti and Al-Filali ${ }^{31}$ who examine the use by Saudi Arabia of investment in media, especially television and newspapers, to further their diplomatic interests; and finally, Pinkerton and Dodds, ${ }^{32}$ who cite the BBC World Service as part of the UK's soft power 'package'. A third group are those commentators in a myriad of media channels in which soft power is cited on a daily basis: this ranges from mainstream newspapers in which lip-service to 'soft power' is paid, but little explanation or definition is offered $;^{33}$ and then there are more academically-focused magazines, blogs and online articles that, at least more frequently, do attempt to provide a partial conceptual explanation. ${ }^{34}$

\footnotetext{
22 Ibid.,

${ }^{23}$ Cerny, P.G. (1997) 'Paradoxes of the Competition State: The Dynamics of Political Globalization', Government and Opposition, 32(2), 251-274.

${ }^{24}$ Keohane, R. O., \& Nye Jr, J. S. (1998). Power and interdependence in the information age. Foreign Affairs, 81-94.

${ }^{25}$ Cf. Nye, J.S. (2003) Propaganda Isn't the Way: Soft Power. Belfer Center for Science and International Affairs [online]. Available: http://belfercenter.ksg.harvard.edu/publication/1240/propaganda isnt the way.html (Accessed: XX).

${ }^{26}$ Nye, J.S. (2002) 'The Information Revolution and American Soft Power', Asia-Pacific Review, 9(1), 60-76.

${ }^{27}$ See for example: Lock, E. (2009) Soft power and strategy: Developing a 'strategic' conception of power. In: Parmar, I. and

Cox, M., eds. (2009) Soft power and US foreign policy: Theoretical, historical, and contemporary perspectives. London: Routledge

${ }^{28}$ See for example: Vuving, A. (2009) How Soft Power Works. Paper presented at American Political Science Association annual

meeting, Toronto, $3^{\text {rd }}$ September. Available at:

http://www.apcss.org/Publications/Vuving $\% 20$ How $\% 20$ soft $\% 20$ power $\% 20$ works $\% 20$ APSA $\% 202009$.pdf and 2012)

${ }^{29}$ Lam, P. E. (2007). Japan's quest for "soft power": attraction and limitation. East Asia, 24(4), 349-363.

${ }^{30}$ Kalin, I. (2011). Soft power and public diplomacy in Turkey. Perceptions: Journal of International Affairs, 16, 5-24.

31 Gallarotti, G. and Al-Filali, I. Y. (2012) 'Saudi Arabia’s soft power', International Studies, 49 (3\&4), 233-261.

32 Pinkerton, A., \& Dodds, K. (2008). Radio geopolitics: broadcasting, listening and the struggle for acoustic spaces. Progress in Human Geography [online]. Available: http://phg.sagepub.com/content/early/2008/09/02/0309132508090978.short

33 See for example: Tryhorn, C. (2013). BBC is in a 'soft power' battle with international broadcasters. The Guardian [online]. Available at: http://www.theguardian.com/media/media-blog/2013/nov/13/bbc-broadcasters-tony-hall-worldwide-audiencecctv-al-jazeera [Accessed 10.10.14]; and Norton-Taylor, N. (2014). 'Soft power' - a key assest in new international order. The Guardian [online]. Available at: http://www.theguardian.com/world/defence-and-security-blog/2014/mar/28/power-militaryculture [Accessed 11.10.14].

34 See: Moss, T. (2013) Soft power? China has plenty. The Diplomat [online]. Available at: http://thediplomat.com/2013/06/softpower-china-has-plenty/ [Accessed 13.10.14]
} 
Finally, a variety of political leaders and national governments have employed the concept: examples here include former Chinese President Hu Jintao's argument for China to enhance its soft power output at the $17^{\text {th }}$ National Congress of the Communist Party of China in $2007 ;^{35}$ Hillary Clinton's reference to both soft power and smart power during her speech at the 2013 Council of Foreign Affairs; ${ }^{36}$ and the British Parliament's 2013 establishment of its 'Committee on Soft Power and the UK's Influence', which led to the publication of two extensive volumes in March 2014.

Perhaps most significantly here, however, is the increasing discussion of soft power in the context of the so-called emerging nation-states. Nye ${ }^{37} 38$ himself has drawn heavily on the soft power of the U.S., detailing the overarching reach of it cultural products, educational and technological excellence, tolerant immigration policies, and political stability. However, due to the inability to fight global poverty, protect the environment, the use of force outside its borders, and the failure of the so-called 'Wall Street model', Nye ${ }^{40} 41$ suggests the general perception is that America's soft power is in decline. ${ }^{42}$ This is complemented, of course, with the rising economic and technological might of countries such as Brazil, Russia, India and China, which, as academic discourse suggests, all have soft power ambitions of their own.

Chinese authorities, for example, are currently engaged in a soft power offensive in order to project a more benevolent and less threatening image of the country. ${ }^{43} 44$ Central here has been the promotion of the Chinese language abroad through the numerous Confucius Institutes based overseas; the prestige and respect gained by various states - mainly in Africa and South America - as a result of the success of the 'Beijing Consensus' in relative comparison to the Washington Consensus; the country's involvement in United Nations peacekeeping missions, humanitarian assistance and disaster relief; and the impressive international reach of its largest media outlets, Central China Television (CCTV) and Xinhua News Agency. ${ }^{46} 474849$

\footnotetext{
35 Nye Jr, J. S. (2010). American and Chinese power after the financial crisis. The W ashington Quarterly, 33(4), $143-153$.

36 Madison, L. (2013) In farewell speech, Clinton calls for 'smart power' on global stage. CBS News [online]. Available at: http://www.cbsnews.com/news/in-farewell-speech-clinton-calls-for-smart-power-on-global-stage/ [Accessed 17.10.14].

37 Nye, J. S. (2004). Soft power and American foreign policy. Political Science Quarterly, 119, 255-270

38 Nye, J. S. Soft power: The means to success in world politics. (New York, NY: Public Affairs, 2004)

${ }^{39}$ Nye Jr, J. S. (2010). Futures of American Power-Dominance and Decline in Perspective, The. Foreign Aff., 89, 2, 1-10.

40 Nye, J. S. (2004). Soft power and American foreign policy. Political Science Quarterly, 119, 255-270

${ }^{41}$ Nye Jr, J. S. (2010). Futures of American Power-Dominance and Decline in Perspective, The. Foreign Aff., 89, 2, 1-10.

42 Cf. Kroenig, M., McAdam, M., \& Weber, S. (2010). Taking soft power seriously, Comparative Strategy, 29(5), $412-431$.

43 Kurlantzick, J. (2007). Charm offensive: How China's soft power is transforming the world. Yale University Press.

44 Wang, Y. (2008). Public diplomacy and the rise of Chinese soft power. The Annals of the American Academy of Political and Social Science, 616(1), 257-273.

45 Bell, D. A. (2009). War, peace, and China's soft power: A Confucian approach, Diogenes, 56(1), 26-40.

${ }^{46}$ Cf. Gill, B., \& Huang, Y. (2006). Sources and limits of Chinese 'soft power'.Survival, 48(2), 17-36.

${ }^{47}$ Cf. Gil, J. (2008). The promotion of Chinese language learning and China's soft power. Asian social science, $4(10)$, P116.
} 
India's drive for soft power rests on attempting to escape its disconnected and extensively deprived past, as well as its belligerence towards Pakistan. ${ }^{50}$ Today, India conjures up notions related to film, business and technology: Bollywood regularly produces more films than its Western counterpart, Hollywood; India's extensive expatriate communities in Europe and America play critical roles in business, healthcare and politics in their new-found-homes; and, perhaps most significantly, there's India's accomplishments in information technology: Infosys Technologies, Wipro, Tata Group, the Reliance Group, the Indian Institute of Management and Indian Institute of Technology have become global names. ${ }^{51} 5253$

Likewise, Brazil has become specifically adept at leveraging soft power, arguably due to its relative lack of military capacity. ${ }^{54}$ Central here has been Brazil's desire to occupy a leading role in successfully negotiating two agreements clarifying the right of World Trade Organization member states to apply various flexibilities available under the Trade Related Intellectual Property Rights, to protect public health; furthermore, in 2001, the Brazilian National AIDS Programme won UNESCO's Human Rights and Culture of Peace Award, earning Brazil much respect and recognition as a global leader in this regard; Brazil is also one of the world's largest aid donors, with an annual spend of roughly US $\$ 4$ billion. ${ }^{55}$

\section{Sports Mega-Events as Part of a Nation's Soft Power Strategy}

While it is clear that soft power now forms part of many nation-state's foreign policy strategies, attention has only recently turned to the role of sports mega-events (SMEs) in this process. For the purpose of this article a simple definition of what constitutes a mega-event is used based on Roche's ${ }^{56}$ work. Roche considered these events to be 'Large-scale, cultural (including commercial and sporting) events, which have a dramatic character, mass popular appeal and international significance'. Such a definition does not, however, take into account the number of visitors an event attracts, the tickets sold, the broadcasting rights around the event or the capital investment

\footnotetext{
${ }^{48}$ Cf. DeLisle, J. (2010). Soft power in a hard place: China, Taiwan, Cross-Strait relations and US policy. Orbis, 54(4), 493-524.

${ }^{49}$ Cf. Ding, S. (2010). Analyzing Rising Power from the Perspective of Soft Power: a new look at China's rise to the status quo power. Journal of Contemporary China, 19(64), 255-272.

50 Pocha, J. (2003). The Rising 'Soft Power' of India and China, New Perspectives Quarterly, 20(1), 4-13.

${ }^{51}$ Cf. Ibid.

52 Cf. Hymans, J. E. (2009). India's Soft Power and Vulnerability. India Review, 8(3), 234-265.

${ }^{3}$ Cf. Blarel, Nicolas (2012) India: the next superpower?: India's soft power: from potential to reality? IDEAS reports [online] Available at: http://eprints.lse.ac.uk/43445/

${ }_{54}$ Dauvergne, P., \& BL Farias, D. (2012). The rise of Brazil as a global development power. Third World Quarterly, 33(5), 903-917.

${ }_{55}$ Cf. Lee, K and Gomes, E.J. (2010) Brazil's ascendance: The soft power role of global health diplomacy. European Business Review [online]. Available at: http://www.aberystwyth.ac.uk/en/media/departmental/interpol/chair/KL---Brazil's-ascendance-article.pdf [Accessed 19.10.14].

${ }_{56}^{6}$ Roche, M. (2002). Mega-Events and Modernity: Olympics and EXPOS in the growth of global culture. Routledge: London (pg. 1).
} 
budget. ${ }^{57}$ Nevertheless, in general, an SME of the first order pertains to the FIFA World Cup and the Olympics; smaller events - often with a major regional impact - are the so-called second order SMEs (for example, the Commonwealth or Pan American Games). Whichever definition is used, sports megas are increasingly being used by states of all political hues to project an image to the outside world, and acquiring and hosting have become key factors in local and national development strategies. ${ }^{58}$

Most specifically in this context are the potential 'legacies' that are said to come with both applying for and hosting SMEs. ${ }^{59}$ A cursory glance at the sport studies literature on SMEs suggests that such legacies range from an increase in the number of a state's citizens participating in sport, ${ }^{60}$ city regeneration, ${ }^{61}$ employment, ${ }^{62}$ tourism gains, ${ }^{63}{ }^{64}$ and a 'feel-good' factor among the hosts' population. ${ }^{65}{ }^{66}$ In the much-cited case of Los Angeles, for example, the staging of the 1984 Summer Olympic Games brought the city a surplus of approximately $f_{2} 215$ million; ${ }^{67}$ in the case of the 1992 Barcelona Summer Olympic Games, the rate of unemployment around the city fell from $18.4 \%$ to $9.6 \%{ }^{68}$ and one of the central objectives behind the hosting of the London 2012 Summer Olympic Games was to increase the rate of sports participation, leading to a fitter and healthier society. ${ }^{69}$

However, it should be made explicit here that, in the majority of cases, SMEs fail to produce the legacies trumpeted in the pre-event rhetoric and that any positive impacts are often difficult to attribute, with confidence, to the event. Moreover, SMEs can actually leave behind a number of negative economic and social consequences for their hosts. ${ }^{70}{ }^{71}$ For example, although sport

57 See: Muller, M. (2015). What makes an event a mega-event?, Leisure Studies [online], Available at: http://www.tandfonline.com/doi/full/10.1080/02614367.2014.993333\#abstract. DOI: 10.1080/02614367.2014.993333

58 Nauright, J., \& Schimmel, K. S. (2005). The political economy of sport. Palgrave Macmillan.

${ }^{59}$ MacAloon, J. J. (2008). 'Legacy'as managerial/magical discourse in contemporary Olympic affairs. The international journal of the history of sport,25(14), 2060-2071.

${ }^{60}$ Girginov, V., \& Hills, L. (2008). A sustainable sports legacy: creating a link between the London Olympics and sports participation. The international journal of the bistory of sport, 25(14), 2091-2116.

${ }^{61}$ Chalkley, B., \& Essex, S. (1999). Urban development through hosting international events: a history of the Olympic Games. Planning perspectives, 14(4), 369-394.

${ }^{62}$ Roche, M. (2000) Mega-Events and Modernity: Olympics and Expos in the Growth of Global Culture. London: Routledge.

${ }^{63}$ Chalip, L., \& McGuirty, J. (2004). Bundling sport events with the host destination. Journal of Sport \& Tourism, 9(3), 267-282.

${ }^{64}$ Kim, N. S., \& Chalip, L. (2004). Why travel to the FIFA World Cup? Effects of motives, background, interest, and constraints. Tourism Management, 25(6), 695-707.

65 Preuss, H. (2007). The conceptualisation and measurement of mega sport event legacies. Journal of sport \& tourism, 12(3-4), 207228.

${ }^{66}$ Grix, J., \& Carmichael, F. (2012). Why do governments invest in elite sport? A polemic. International journal of sport policy and politics, 4(1), 73-90.

${ }^{67}$ Cf. Gratton, C., Dobson, N., \& Shibli, S. (2000). The economic importance of major sports events: a case-study of six events. Managing leisure, 5(1), 17-28.

${ }^{68}$ Cf. Miguélez, F., \& Carrasquer, P. (1995). The repercussion of the Olympic Games on labour. The Keys to Success, in Moragas., M. and Botela., M.(eds)). Centre d'Estudis Olimpics $i$ de l'Esport, Universitat Autonoma de Barcelona, Barcelona.

69 Girginov, V., \& Hills, L. (2008). A sustainable sports legacy: creating a link between the London Olympics and sports participation. The international journal of the history of sport, 25(14), 2091-2116.

${ }_{70}$ Cf. Mules, T., \& Faulkner, B. (1996). An economic perspective on special events. Tourism Economics, 2, 314-329. 
events have been considered to be effective additions to the economic development of cities and states, in numerous cases they result in a post-event legacy of 'white elephants', that is underused sporting facilities. In addition, most mega-events cost billions of dollars to stage and often result in a large financial burden for the host cities and states. ${ }^{72}$ The 1972 Olympic Games, for example, left Munich with debts of up to $£ 178$ million; and four years later in Montreal the Games provided debts of up to $f_{6} 692$ million, ${ }^{73}$ famously taking 30 years for taxpayers to redeem. Furthermore, beliefs surrounding positive legacy regeneration, ${ }^{74}$ employment, ${ }^{75}$ the so-called feel-good factor, ${ }^{76}$ and increases in sports participation ${ }^{77}$ have also been questioned by countless academics. Supposed tourism gains, too, are also said to be drastically overstated: the 2002 FIFA World Cup in Japan and South Korea, for example, proved to be wildly optimistic, with Japan attracting only 30,000 more visitors and South Korea reporting the same number as the previous year. $^{78}$

The reason why states continue to strive to host SMEs is understood by many as an attempt to improve their nation's image by profiling and showcasing themselves globally and 'attracting' others. ${ }^{79} 8081$ As such, numerous scholars consider SMEs to be a vital part of a government's contemporary soft power strategy. ${ }^{82} 83 \quad 84 \quad 85$ Indeed, with their unprecedented global audiences, ${ }^{86} 87$ and valuable promotional opportunities for cities and states, ${ }^{88} 89$ national leaders

\footnotetext{
${ }^{71}$ Cf. Andranovich, G., Burbank, M. J., \& Heying, C. H. (2001). Olympic cities: lessons learned from mega-event politics. Journal of urban affairs, 23(2), 113-131.

72 Essex, S., \& Chalkley, B. (2004). Mega-sporting events in urban and regional policy: a history of the Winter Olympics. Planning Perspectives, 19(2), 201-204.

73 Gratton, C., Dobson, N., \& Shibli, S. (2000). The economic importance of major sports events: a case-study of six events. Managing leisure, 5(1), 17-28.

74 Preuss, H. (2007). The conceptualisation and measurement of mega sport event legacies. Journal of sport \& tourism, 12(3-4), 207228.

75 Toohey, K. and Veal, A. J., 2007. The Olympic Games: A Social Science Perspective, 2nd edition, CABI Publishing, Wallingford, Oxon, UK.

76 Grix, J., \& Carmichael, F. (2012). Why do governments invest in elite sport? A polemic. International journal of sport policy and politics, 4(1), 73-90.

77 Girginov, V., \& Hills, L. (2008). A sustainable sports legacy: creating a link between the London Olympics and sports participation. The international journal of the history of sport, 25(14), 2091-2116.

${ }_{78}$ Horne, J. D., \& Manzenreiter, W. (2004). Accounting for Mega-Events Forecast and Actual Impacts of the 2002 Football World Cup Finals on the Host Countries Japan/Korea. International Review for the Sociology of Sport, 39(2), 187-203.

${ }^{79}$ Cf. Horton, P. (2008). Sport as public diplomacy and public disquiet: Australia's ambivalent embrace of the Beijing Olympics. The International Journal of the History of Sport, 25(7), 851-875.

${ }^{80}$ Cf. Deos, A. (2013). Sport and relational public diplomacy: the case of New Zealand and Rugby World Cup 2011. Sport in Society, (ahead-of-print), 1-17.

${ }^{81}$ Knott, B., Fyall, A., \& Jones, I. (2013). The nation-branding legacy of the 2010 FIFA World Cup for South Africa. Journal of Hospitality Marketing \& Management, 22(6), 569-595.

82 Finlay, C. J., \& Xin, X. (2010). Public diplomacy games: a comparative study of American and Japanese responses to the interplay of nationalism, ideology and Chinese soft power strategies around the 2008 Beijing Olympics. Sport in Society, 13(5), 876900.

83 Manzenreiter, W. (2010). The Beijing games in the western imagination of China: The weak power of soft power, Journal of Sport and Social Issues, 34, 29-48.

${ }^{84}$ Freeman, K. (2012). Sport as swaggering: utilizing sport as soft power. Sport in Society, 15(9), 1260-1274.

85 Grix, J., \& Houlihan, B. (2014). Sports Mega-Events as Part of a Nation's Soft Power Strategy: The Cases of Germany (2006) and the UK (2012). The British Journal of Politics \& International Relations, 16(4), 572-596.

86 Roche, M. (2002) Mega-Events and Modernity: Olympics and Expos in the Growth of Global Culture. London: Routledge.
} 
regularly justify their investment in SMEs in terms of promoting their country's image and gaining international prestige, transcending provincialism and historic insecurities, and embracing globality, competitiveness, and excellence..$^{90}$

Most precisely here, hosting SMEs successfully is increasingly acknowledged to be a highly visible and potentially positive signal to other countries, ${ }^{91}{ }^{92}$ acting as a valuable asset in accelerating their entry to, and acceptance within, the world's mature economies. ${ }^{93}$ In this sense, international sporting success, whether by athletic competition or the effective staging of an SME, provides the perfect opportunity for national leaders who seek to 'attract' others with their values and culture and persuade them to want what they want by projecting specific images, principles, achievements and visions to foreign publics, ${ }^{94}$ echoing, in many cases, descriptions of excellence, fairness and, most importantly in a soft power context, universal friendship and mutual cooperation and exchange. ${ }^{95}$

Australia is an example of a state successfully using an SME to project a positive image of itself. With home-team advantage, the Australians were able to both perform above expectations in sport and host a highly successful Summer Olympic Games in $2000 .{ }^{96}$ Equally, the co-hosting of the 2002 FIFA World Cup laid the groundwork for future internationalism and cooperation between Japan and South Korea - nations that had a long historical opposition towards one another. ${ }^{97} 98$ Additionally, the case of Germany, whose image was severely tarnished by the legacy of the Third Reich and the barbarity of the Nazis, indicates how the 2006 FIFA World Cup was

\footnotetext{
87 Andrews, D. L. (2003). Sport and the transnationalizing media corporation. The Journal of Media Economics, 16(4), $235-251$.

${ }^{88}$ Black, D., \& Van der Westhuizen, J. (2004). The allure of global games for 'Semi-peripheral' polities and spaces: A research agenda. Third World Quarterly, 25, 1195-1214.

${ }^{89}$ Nauright, J. (2004). Global games: culture, political economy and sport in the globalised world of the 21 st century. Third World Quarterly, 25(7), 1325-1336.

${ }^{90}$ Grix, J., \& Lee, D. (2013). Soft power, sports mega-events and emerging states: The lure of the politics of attraction. Global Society, 27(4), 521-536.

${ }^{91}$ Finlay, C. J., \& Xin, X. (2010). Public diplomacy games: a comparative study of American and Japanese responses to the interplay of nationalism, ideology and Chinese soft power strategies around the 2008 Beijing Olympics. Sport in Society, 13(5), 876900 .

${ }^{92}$ Cornelissen, S. (2011). More than a sporting chance? Appraising the sport for development legacy of the 2010 FIFA World Cup. Third World Quarterly, 32(3), 503-529.

93 Grix, J., \& Lee, D. (2013). Soft power, sports mega-events and emerging states: The lure of the politics of attraction. Global Society, 27(4), 521-536.

94 Grix, J., \& Lee, D. (2013). Soft power, sports mega-events and emerging states: The lure of the politics of attraction. Global Society, 27(4), 521-536.

95 Manzenreiter, W. (2010). The Beijing games in the western imagination of China: The weak power of soft power, Journal of Sport and Social Issues, 34, 29-48.

${ }^{96}$ Cf. Black, D. (2007). The symbolic politics of sport mega-events: 2010 in comparative perspective. Politikon, 34(3), 261-276.

97 Jarvie, G. (2003). Internationalism and Sport in the Making of Nations.Identities: Global Studies in Culture and Power, 10(4), $537-$ 551.

${ }^{98}$ Cf. Horne, J. D., \& Manzenreiter, W. (2004). Accounting for Mega-Events Forecast and Actual Impacts of the 2002 Football World Cup Finals on the Host Countries Japan/Korea. International Review for the Sociology of Sport, 39(2), 187-203.
} 
able to go some considerable way to altering foreign publics' negative view of the country. ${ }^{99}$ Finally, the 2010 FIFA World Cup was able to portray the tournament as an 'African showpiece' - an instrument of continental unity, friendship, solidarity and peace between the state and the rest of the African continent. ${ }^{100} 101$

\section{Methods}

Our data collection strategy involved a series of three stages with which to unpack the role of SMEs in the Brazilian and UK soft power strategies.

First, we conducted a thorough analysis of documents surrounding London's hosting of the 2012 Olympic Games, and Brazil's staging of the 2014 FIFA World Cup and acquisition of the 2016 Summer Olympic Games. In looking to ensure we only incorporated into our sample documents that had an authentic origin and provided credible and factual accuracy, we followed the below inclusion-exclusion criteria (See Figure 1).

\begin{tabular}{|c|c|c|}
\hline & Included & Excluded \\
\hline Newspapers & $\begin{array}{c}\text { Broadsheets (The Guardian, } \\
\text { The Telegraph, The Times, } \\
\text { etc.) }\end{array}$ & $\begin{array}{c}\text { Tabloids (The Sun, The } \\
\text { Daily Mirror, The Daily Star, } \\
\text { etc.) }\end{array}$ \\
\hline Virtual & $\begin{array}{c}\text { Other international news } \\
\text { agencies (BBC, Reuters, } \mathrm{Al} \\
\text { Jazeera, etc.) }\end{array}$ & $\begin{array}{l}\text { All 'social media' (forums, } \\
\text { blogs, networks, etc.) }\end{array}$ \\
\hline $\begin{array}{l}\text { Government } \\
\text { Documents }\end{array}$ & $\begin{array}{l}\text { Documents published } \\
\text { directly from - or backed- } \\
\text { up by - official state } \\
\text { departments. }\end{array}$ & $\begin{array}{l}\text { Documents unable to be } \\
\text { backed-up by official state } \\
\text { publications }\end{array}$ \\
\hline $\begin{array}{l}\text { Non-State } \\
\text { Documents }\end{array}$ & $\begin{array}{c}\text { Documents published } \\
\text { directly from - or backed- } \\
\text { up by - well-known NGOs } \\
\text { (Amnesty, Green Peace, } \\
\text { Transparency } \\
\text { International, etc.) }\end{array}$ & $\begin{array}{l}\text { Documents from } \\
\text { unknown NGOs and/or } \\
\text { those unable to be backed- } \\
\text { up by well-known NGO } \\
\text { publications }\end{array}$ \\
\hline $\begin{array}{l}\text { Private-Sector } \\
\text { documents }\end{array}$ & $\begin{array}{l}\text { Documents published } \\
\text { directly from - or backed- } \\
\text { up by - well-known } \\
\text { private-sector companies } \\
\text { (Nike, Adidas, GfK } \\
\text { Group, etc.). }\end{array}$ & $\begin{array}{c}\text { Documents from } \\
\text { unknown private-sector } \\
\text { companies and/or those } \\
\text { unable to be backed-up by } \\
\text { publications from well- } \\
\text { known private-sector } \\
\text { companies }\end{array}$ \\
\hline
\end{tabular}

\footnotetext{
${ }^{99}$ Grix, J., \& Houlihan, B. (2014). Sports Mega-Events as Part of a Nation's Soft Power Strategy: The Cases of Germany (2006) and the UK (2012). The British Journal of Politics \& International Relations, 16(4), 572-596.

100 Cornelissen, S. South Africa's 'Coming Out Party': Reflections on the Significance and Implications of the 2010 FIFA World Cup. In J. Grix (Ed.), Leveraging legacies from sports mega-events. Palgrave: Basingstoke.

101 Pillay, U., \& Bass, O. (2008). Mega-events as a response to poverty reduction: The 2010 FIFA World Cup and its urban development implications, Urban Forum, 19, 329-346.
} 
Figure 1: Document collection inclusion-exclusion criteria

Second, we conducted a number of informal interviews with key officials from the Brazilian Ministry of Sport in April, 2013 and November, 2014, in Brasilia and Sao Paulo where one of the authors held academic workshops and meetings. Finally, during both visits to Brazil, field notes were taken, whereby we visited key cultural sites and sporting venues and attended various conferences and seminars.

\section{The London Olympics, 2012}

The British Foreign and Commonwealth Office (FCO) has generally adopted a disdainful attitude towards the concept of soft power in part because the habits of hard power are difficult to break. Since 1914 there have been few if any years when British forces have not been at war in some part of the world. ${ }^{102}$ Nevertheless, soft power resources have not been totally absent from the foreign policy repertoire with the work of the British Council and the BBC World Service being long-standing examples. ${ }^{103}$ Even sport, initially in the form of the British Empire Games and currently as the Commonwealth Games, has been used as a soft power resource for over eighty years. While the initial form of the Games were a celebration of the British Empire the more recent iterations have become the most visible indication of the survival of the Commonwealth as a political institution. However, the increased symbolic importance of the Commonwealth Games for Britain and for other Commonwealth member states has been inadvertent rather than planned and a consequence of the increasingly sclerotic nature of the Commonwealth as an institution which has allowed symbolism to compensate for the lack of substance.

It was against this backdrop of a preference for hard power and a lack of obvious interest in the utilization of soft power that Britain was awarded in 2005 the right to host the world's most important sport event - the Summer Olympic and Paralympic Games - and, in consequence, the opportunity to exploit a significant soft power opportunity. The embrace of this opportunity by the British Foreign Office and Commonwealth was dutiful rather than enthusiastic. The Carter Report ${ }^{104}$ into public diplomacy commented on the 'untapped potential' of sport to 'reach a wide range of target audiences with diverse economic and social backgrounds' and suggested that the

\footnotetext{
102 Britain's 100 years of conflict. Available from: http://www.theguardian.com/uk-news/nginteractive/2014/feb/11/britain-100-years-of-conflict Accessed 21.10.2014.

103 Wilton Review. (2003) Public Diplomacy Review. London: Foreign and Commonwealth Office.

${ }^{104}$ Carter Report (2005) Public Diplomacy Review (chair, Lord Carter of Coles) London: Foreign and Commonwealth Office.
} 
potential value of sport should 'continue to be explored'. A report to the House of Commons Foreign Affairs Committee, by the British Council in the same year noted the opportunity presented by the hosting of the Olympic and Paralympic Games to build international understanding among young people in Britain and in other countries. ${ }^{105}$ Despite the lack of a tradition of using soft power resources the FCO did allocate a small budget to exploit the opportunity that the 2012 Games presented and the high profile that Team GB would have during the Games. The starting point for the sport soft power strategy was an assessment of the then current international image of the UK commissioned by the FCO in 2005. The evidence, as reported to the House of Commons Foreign Affairs Committee ${ }^{106}$ painted a mixed picture. The international profile of the UK was sharply defined, but the positive elements, that the country was 'fair, innovative, diverse, confident and stylish', were set against a more negative perception of a country that was 'arrogant, stuffy, old-fashioned and cold'. The image that the FCO wanted to project was of a 'modern Britain ... open (welcoming, diverse, tolerant), connected (through our involvement in the UN and G20, politically, geographically, in terms of trade and travel), creative and dynamic' ${ }^{107}$ The 2012 Games were acknowledged by the FCO as an opportunity not only to address the negative elements in the international perception of the UK and engineer a repositioning of the UK brand, but also to target particular issues and countries. In response to this opportunity the FCO devised a strategy for the two years prior to the Games designed to achieve a range of objectives, namely: enhancing the general brand image of the country; encouraging inward investment and boosting exports; and addressing national security issues. More specifically the FCO was concerned to redefine brand UK and to use the Olympics 'to promote British culture at home and abroad [and to] cement Britain's reputation as a...vibrant, open and modern society, a global hub in a networked world'. The second objective was to 'bolster the UK economy, increase commercial opportunities for British business in target countries and secure high value inward investment' and could also be considered to be similarly concerned with shaping the perception of the UK among potential inward investors. The third objective was more specifically targeted and was to 'enhance our security by harnessing the

\footnotetext{
105 House of Commons (2005-06) Foreign Affairs Committee, $3^{\text {rd }}$ Report, Public diplomacy (London: The Stationery Office) (Ev5).

${ }^{106}$ House of Commons (2005-06) Foreign Affairs Committee, $3^{\text {rd }}$ Report, Public diplomacy (London: The Stationery Office) (FCO Written Evidence, para. 20, 2011).

107 House of Commons 2005-06, FCO Written Evidence, para. 20, 2011
} 
global appeal of the Olympics, particularly among the young, to reinforce values of tolerance, moderation and openness'. ${ }^{108}$

The expectation that a nation's brand can be significantly affected by a single event is perhaps overly optimistic unless of course if the event has problems. The Olympic Games in 2004 and the Commonwealth Games in 2010 tended to impact negatively on the brand image of Athens and Delhi respectively in terms of efficiency and effectiveness and the 2014 Sochi winter Olympics tended to project an image of profligacy and corruption. The problem facing the UK was that, unlike Greece, India and Russia, the country had enjoyed a generally positive international image as measured by the Anholt-Gfk Roper Index for some time. In both 2009 and 2010 the UK ranked fourth. Consequently a successful Olympic and Paralympic Games was unlikely to significantly improve the nation's image while an unsuccessful Games could certainly damage the brand. As it turned out the international media perception of the 2012 Games was almost uniformly positive. ${ }^{109}$ London benefitted, in particular, and was seen as a good place to do business. There is no evidence that the Games negatively affected that perception. In the element of the Anholt-Gfk Roper Index which specifically measures investment appeal the UK ranked third in both 2012 and 2013 (behind Germany, Canada and the USA). ${ }^{110}$

The third sport soft power objective related to threats to domestic and international security arising from conflicts in the Middle East. The UK government has supported either directly or indirectly a number of Olympic legacy projects targeted at countries in the Middle East. The International Inspirations project which is managed by the British Council in conjunction with UNESCO, the Youth Sport Trust (a UK-based sport charity) and UK Sport which aims to improve the quality of physical education available to children. The project was launched in 2005 following the award of the Olympic and Paralympic Games to London and has delivered programmes in over twenty countries including Egypt, Jordan, Pakistan and Turkey. A second, but contrasting sport soft power initiative is the financial support given by the British Consulate in Jerusalem to the Speed Sisters - an all-female rally team based in Palestine. More directly related to the Olympics is the recruitment of well-known Olympians and Paralympians such as Sir Steve Redgrave, Lady Tanni Grey Thompson and Chris Holmes as ‘Olympic Ambassadors’.

\footnotetext{
${ }^{108}$ House of Commons (2010-11) Foreign Affairs Committee, 2 ${ }^{\text {nd }}$ Report, FCO Public Diplomacy: The Olympic and Paralympic Games 2012 (London: The Stationery Office) (Ev19)

109 Grix, J., \& Houlihan, B. (2014). Sports Mega-Events as Part of a Nation's Soft Power Strategy: The Cases of Germany (2006) and the UK (2012). The British Journal of Politics \& International Relations, 16(4), 572-596.

110 US voted top country for attracting talent and investment but with a reducing lead. Available from: http://www.gfk.com/news-and-events/press-room/press-releases/pages/nation-brand-index-2013-latestfindings.aspx, Accessed 22.10.2014.
} 
In recent years these ambassadors have to visit selected countries including Israel, Jordan and Palestine.

While the domestic and international perception of the London 2012 Games was generally very positive it is difficult to assess the utility of diplomatic value of sport as a soft power resource. While it is doubtful that UK sport diplomacy had a negative impact on the pursuit of the UK government's foreign policy objectives it is difficult to determine the extent to which a positive impact was generated. Where countries have either eschewed the use of hard power, as is the case with Germany and Japan, or simply do not possess a significant hard power capability sport soft power is, by default, a relatively significant resource and potentially effective resource. However, where a country is still giving prominence to the hard power resources in its diplomatic portfolio, as is the case with the UK, it is doubtful whether the deployment of sport soft power resources is capable of doing more than reinforcing hard power objectives.

\section{Brazil's 'Double Host' Status}

On the surface Brazil would appear to fit the classic typology of an 'emerging state' or 'rising power', one which attempts to use a variety of strategies to announce its arrival on the world stage, often burnishing its image and attracting tourists to its shores. As discussed, hosting SMEs are certainly part of a broader concerted 'soft power' strategy; ${ }^{111}$ however, there are a number of issues that set Brazil apart from other so-called 'BRICS' countries (Russia, India, China and South Africa). Generic themes of 'image leveraging' bind hosting states across the political spectrum from the UK to Qatar - especially after Germany's successful image overhaul, in part through staging the FIFA World Cup in 2006 - but Brazil is unique in a number of ways. In Brazil's case, for instance, it is not simply to announce that it is ready 'to signal [its] "graduation" to the status....of advanced state" 112 - that is, move from the periphery to the core but to indicate its shift from a regional actor to a global actor in international affairs. In what follows we focus on both the international and domestic legacies, deriving from what we term Brazil's 'double host' status.

Brazil is at the forefront of the emerging powers discourse - although at the time of writing attempts were being made to distinguish the next batch of economic powerhouses, the 'MINT' group (Mexico, Indonesia, Nigeria and Turkey). A sign of Brazil's global economic power came

\footnotetext{
111 Grix, J., \& Houlihan, B. (2014). Sports Mega-Events as Part of a Nation's Soft Power Strategy: The Cases of Germany (2006) and the UK (2012). The British Journal of Politics \& International Relations, 16(4), 572-596.

112 Black, D. and Van Der Westhuizen, J. (2004). The allure of global games for 'semi-peripheral' polities and spaces: a research agenda, Third World Quarterly, 25(7), 1195-1214. (pg. 1206).
} 
towards the end of 2011 when it overtook the UK to become the world's sixth largest economy. ${ }^{113}$ Brazil's rise is clearly not just economic. Its ambition is to play a role in international affairs commensurate with its size, which is evident in:

a. its recent attempt to gain a permanent seat at the UN Security Council;

b. taking over the command of a peacekeeping mission in Haiti and

c. its recent attempt, along with Turkey, to intermediate a nuclear deal with Iran.

While wider debates rage about the ways in which Brazil will exercise its newly found power in the international system, the unprecedented hosting of the two largest SMEs in the world has received far less scrutiny. Brazil's double host status is likely to be matched by political influence on the world stage, as former hosts China and South Africa have demonstrated. The latter are, post event, established participants in multilateral summits such as the G20.

On hearing that Rio would host the 2016 Olympics the then president of Brazil, Luiz Inacio Lula da Silva, stated 'The world has recognised that the time has come for Brazil'. He went on to suggest in an emotional address that 'Today I've felt prouder of being Brazilian than on any other day. Today is the day that Brazil gained its international citizenship.....Today we earned respect.' Rohter ${ }^{114}$ puts this in perspective and suggests that Brazilians want Brazil to be taken seriously 'especially by the countries it views as great powers'. International recognition is, as discussed above, central to a soft power strategy.

Brazil is, of course, no novice at showcasing itself through large scale events: the successful (from the outside) staging of the 2007 Pan American Games was clearly a precursor to winning the right to host both the 2014 World Cup and the 2016 Olympic Games. This was followed by the successful hosting of the global Rio+20 Sustainable Development Conference in 2012 and the World Youth Journey - a Catholic event held in Rio in 2013, an event the Pope Francis deemed important enough to attend. ${ }^{115}$

However, winning the bidding process for the Olympics or World Cup usually sends out a number of positive signals of inclusion and acceptance in the international system: being chosen for two in short succession suggests that the IOC and FIFA have enough trust in Brazil to put on successful events and a belief that it can put its 'historical in-fighting to one side, streamline

\footnotetext{
113 Guardian (2012) 'Brazil's economy overtakes UK to become world's sixth largest' at: http://www.theguardian.com/business/2012/mar/06/brazil-economy-worlds-sixth-largest 114 Rohter (2010: 224) Brazil on the Rise. The Story of a Country Transformed. Basingstoke: Palgrave Macmillan. 115 World Youth Journey Organisation (2014) at http://wydcentral.org/ accessed on 13.02.14.
} 
its culture of opaque bureaucracy and clamp down on the rampant corruption linked to its political elite'. ${ }^{116}$ That is, it needs to re-fashion the unattractive elements of its political culture. The latter is reflected in Brazil's $72^{\text {nd }}$ spot in the 2013 'corruption index' put together by the NGO 'Transparency International ${ }^{117}$, joint with South Africa and eight places above China.

Apart from international legacies, Brazil's motives for hosting are as much about 'domestic' legacies than anything else. While global exposure is central to Brazil's soft power strategy, there is a feeling that this large country of almost 200 million inhabitants has, for too long, been a 'sleeping giant'. Brazil has, since Stefan Zweig's prognosis of Brazil as the 'Land of the Future' in 1941, struggled under a sense of burden of expectation. ${ }^{118}$ Carvalho, ${ }^{119}$ in his analysis of Brazilian national myths and heroes, argues that the original myth of Brazil (as a country) is not related to political institutions, for example, democracy and the monarchy in the UK, but is rather related to its nature and its enormous size. The Brazilian national consciousness has been linked, since the nation's creation, to the expanse of the country's nature and the expectation of a bright future. Carvalho et. al., ${ }^{120}$ gets to the root of the Brazilian paradox when he suggests that:

The drama of the country lies in the contrast between dream and reality, aspiration and achievement. [...]. Aspirations are not accompanied by appropriate actions to accomplish them. People do not trust in their leaders and institutions, but do not do anything to make the former more responsible for public social needs and to change the development of the latter [...] Hence a feeling of frustration, disappointment with the government and institutions, and the permanence of a vague hope that a possible messiah can come up with the solution to all problems.

During his two terms in office (2003-2006 and 2007-2010), the former president, Lula, used to refer to himself as this messiah, arguing that his government would do for the country much more than the previous governments in Brazil's history put together. It was (and has been) a very effective rhetorical tool, which contributed to his charismatic legitimacy. Lula adopted a political strategy based on a discourse made up of this imagery of Brazil as the 'land of the future' and enacted measures which underpinned this imagery in practice.

It is worth noting that Lula's rhetoric, drawing on the 'land of the future' notion discussed above, was particularly to the fore when speaking of SMEs. For example, at the ceremony in

\footnotetext{
116 Ibid.

117 Transparency International (2014) 'Corruption Perception Index 2013', at http://www.transparency.org/cpi2013/results, accessed 13.02.14.

118 Rohter, L (2012). Brazil on the Rise: The Story of a Country Transformed. Basingstoke: Palgrave Macmillan.

119 Carvalho, José Murilo de. (2003) Nação imaginária: memória, mitos e heróis. In: NOVAES, Adauto (org.). A crise do estado-nação. Rio de Janeiro: Civilização Brasileira, p.395-418.

120 Ibid., p. 14.
} 
which the Brazilian Federal Government officially announced its support for Rio’s Olympic bid, Lula used his trademark superlatives stating:

If this country could organize the Pan-American Games like it did, in such a short space of time, why can't we organize the best Olympic Games that has ever taken place in any country? (Brasil 2008)

After winning the right to host the 2014 FIFA World Cup and the 2016 Olympics in 2006, the next stage was to implement the commitments set out in the respective bids. To ensure the completion of both events according to the proposed guidelines, a set of measures has been adopted by the Local Organizing Committees as well as by municipal, state and federal governments. Among them, the most relevant are: a) the construction and/or reform of sports facilities; b) investment in infrastructure, especially those related to transport, such as airports and underground train systems; c) the adaptation of the Brazilian legal framework, in order to ensure a 'fit' with the requirements demanded by FIFA and IOC.

In 2007 President Lula had suggested that no public money would be spent on the World Cup. At this time there was considerable debate about budget overspend and corruption with monies belonging to the people being siphoned off. Subsequent events made hollow Lula's promise: the Federal Government not only had to pump resources into the construction of stadia, but had to make up the short-fall of ever increasing regional budgets. Officially, the exponential rise in costs for the World Cup has been attributed to FIFA's demands; the late delivery of the World Cup infrastructure, unfinished at the time of writing, reveals the gap between Government rhetoric and the reality on-the-ground.

The building of transport infrastructure, designed to provide better mobility to and within host cities, is also presenting many problems. One of the primary legacies promised was the construction or reform of airports, underground trains, high-speed train systems and so on. These projects have taken much longer than initially planned. Furthermore, a number of projects have been postponed (to after the World Cup) or even cancelled. Finally, the adaptation of the Brazilian legal framework was necessary because some of the commitments taken on by Brazil were not covered by national legislation. These 'pre-event institutional legacies ${ }^{\text {,21 }}$ resulted in the enactment of two laws: the so-called Olympic Act (Law n $\left.{ }^{\circ} 12.035 ; 1.10 .09\right)$ and the General Law of the World Cup (Law no 12.663; 5.06.12). Both set out special rules for, respectively, the 2016 Olympics and 2013 FIFA Confederations Cup/2014 FIFA World Cup, allowing the removal of

121 Toledo, R. M. Grix, J. and M. T. S. Bega (2015) 'Megaeventos Esportivos e seus Legados: uma análise dos efeitos institucionais da dupla condição do Brasil de país-sede’, Revista de Sociologia e Política, in press. 
any known legal rule which, in the eyes of FIFA or IOC, could represent an obstacle to the completion of their events in Brazil.

All of the above impacts on the potential for any long-term legacies from Brazil's two SMEs. The effect has been growing popular dissatisfaction with the rising costs and expenditure related to both events. Demonstrators took to the streets to protest against the lack of resources for basic educational and health policies. An example of this dissatisfaction could be observed during the 2013 Confederations Cup, held in five of the twelve host cities of the 2014 World Cup. There were many popular protests against the costs of the latter with demands for resources for schools and hospitals. Both the Brazilian and FIFA Presidents, Dilma Roussef and Joseph Blatter, were booed by the crowd at the opening ceremony and FIFA's representatives were harassed by protesters. It is this type of public reaction that has led some to label SMEs 'double-edged swords', simultaneously holding the capacity to result in both soft power or soft 'disempowerment'. ${ }^{122} 123124$

\section{Conclusion}

This article has set out to interrogate the use of sports mega-events as part of state's soft power strategies by focusing on both an advanced capitalist state (the UK) and an 'emerging' state (Brazil). The rationale behind this endeavor was to shed light on, and clarify, the concept of 'soft power', which has, up until now, not been used widely in relation to sport.

The acquisition and successful hosting of such SMEs is now looked upon as a significant 'litmus test' for would-be leading states globally. Although the precise mechanisms through which a state is said to gain in soft power due to hosting a successful SME are not clear, showcasing the ability to deal with the logistics of such an event appears to be crucial to how hosts are viewed by others.

While the concept of soft power, as suggested in this article, is of use as a lens through which to understand why states wish to host sports mega-events, it is a broad-brush concept that does not allow for the nuances between states: whereas the UK's image abroad was very positive before

\footnotetext{
122 Grix, J. (2013) 'The Risks and Rewards of Hosting Sports Mega-Events', ICC Journal (International Centre for Sport Security), 1, 1, pp. 22-27.

123 Brannagan, P.M. and Giulianotti, R. (2014). Qatar, Global Sport, and the 2022 FIFA World Cup. In Grix, J. (ed.), Leveraging Legacies from Sports Mega-Events: Concepts and Cases. Basingstoke: Palgrave.

124124 Brannagan, P.M. and Giulianotti, R. (2014). Soft Power and Soft Disempowerment: Qatar, Global Sport and football's 2022 World Cup Finals, Leisure Studies [Online]. Available at: http://www.tandfonline.com/doi/full/10.1080/02614367.2014.964291\# [Accessed: 9th January 2015].
} 
the event and to better this was not the key aim, Germany used the 2006 World Cup to alter a tarnished image; Brazil, on the other hand, does not suffer from a negative image abroad, but wishes to consolidate its regional power position on the global stage. Thus, the use of similar SMEs are not always for parallel reasons, despite being part of states' much wider soft power strategies. There are a number of ways in which a state's use of SMEs could be compared across cases; however, a direct, comparative method of analysis misses a number of key points. First, as we have sought to make clear, successful and wealthy advanced capitalist states, such as Germany, have a very different resource base, including infrastructure, from which to launch a sports-related soft power strategy than a so-called 'emerging state'. Germany did not need to convince a doubtful electorate of the need to invest in roads, transport links and other logistics, as all these existed before the event took place. ${ }^{125}$ Equally, given that Germany has little "hard power' to speak of, it was able to focus almost exclusively on leveraging a positive image globally. Brazil, on the other hand, is not in the same position financially and does not have over fifty years of democratic rule under its belt. Equally, it would be a mistake to assume that Brazil is simply using its double host status as a Trojan Horse for neo-liberal reforms that will push the country towards as more 'developed' status. Such a reading is a narrow and linear understanding of development in terms of a growing global power. What is clear, however, is that while the use of sports mega-events appears to have become part and parcel of most states' soft power packages, the benefits that are said to derive from hosting them remain over-stated, over-inflated and under researched. It is hoped that the ideas put forward in this paper can form the basis of future work on the role of sports mega-events in states' soft power strategies. It is clear, however, that there is a need to understand the mechanisms by which soft power actually assists states in gaining international prestige how they can prevent such strategies backfiring and leading to 'soft disempowerment'. ${ }^{126}$

Past research indicates that societies with deep structural divides and fault lines - inequality in society, poverty, high-crime, corruption etc. - are very unlikely to change as a result of an SME or any hoped-for legacy. Shortly before, during and after, sport certainly papers over such cracks, but without fundamental reform and the will to change, cracks soon reappear once the perennial sport circus rolls out of town and on to the next.

\section{Acknowledgements}

125 Grix, J., \& Houlihan, B. (2014). Sports Mega-Events as Part of a Nation's Soft Power Strategy: The Cases of Germany (2006) and the UK (2012). The British Journal of Politics \& International Relations, 16(4), 572-596.

126 Brannagan, P.M. and Giulianotti, R. (2014). Soft Power and Soft Disempowerment: Qatar, Global Sport and football's 2022 World Cup Finals, Leisure Studies [Online]. Available at: http://www.tandfonline.com/doi/full/10.1080/02614367.2014.964291\# [Accessed: 9th January 2015]. 
The authors would like to thank Renata Toledo for her help with the section on Brazil, in particular for providing the legal documents to make our argument.

\section{About the Authors}

Jonathan Grix is a Reader in Sport Policy and Politics in the School of Sport, Exercise and Rehabilitation Sciences, Director of the Sport Policy Centre and Head of the Sport Pedagogy and Sport Policy research and teaching group at the University of Birmingham. His latest books include Sport under Communism. Behind the East German 'Miracle' (Palgrave, 2012); (ed. with Lesley Phillpots) Understanding UK Sport Policy in context (Routledge, 2014) and Sport Politics: An Introduction (Palgrave, 2015).

Paul Michael Brannagan is a Doctoral Researcher of Sociology within Loughborough University's School of Sport, Exercise and Health Sciences, and a Teaching Fellow in Sport Policy and Politics at the University of Birmingham's School of Sport, Exercise and Rehabilitation Sciences. He is one of the few scholars concentrating on the contemporary influence of modern sport in the Middle East, with a particular focus on the State of Qatar and its acquisition of the 2022 FIFA World Cup finals. Through this, Paul has uncovered the crucial role sport is playing in Qatar's wider socio-political objectives.

Barrie Houlihan is Professor of Sport Policy at Loughborough University, UK and Visiting Professor at the Norwegian School of Sport Sciences. His research interests include the domestic and international policy processes for sport. He has a particular interest in sports development, the diplomatic use of sport, and drug abuse by athletes. He has authored or edited 20 books and over 50 journal articles. His most recent books are Participation in Sport (ed. with M. Nicholson and R. Hoye), and Sport Policy in Britain (with Iain Lindsey) (2012). He is the editor-in-chief of the International Journal of Sport Policy and Politics. 